\title{
Lusotopie
}

Recherches politiques internationales sur les espaces

issus de l'histoire et de la colonisation portugaises

$\mathrm{XV}(1) \mid 2008$

Indiens du Mozambique et d'Afrique orientale

\section{Ambivalence and Phantasm in the Portuguese Colonial Discursive Production on Indians (Mozambique)}

Ambivalence et fantasme dans la production discursive coloniale portugaise sur les Indiens (Mozambique)

Ambivalência e fantasma na produção discursiva colonial portuguesa sobre os

Indianos (Moçambique)

\section{Susana Pereira Bastos}

\section{(2) OpenEdition}

Journals

Electronic version

URL: http://journals.openedition.org/lusotopie/781

ISSN: 1768-3084

\section{Publisher:}

Association des rechercheurs de la revue Lusotopie, Brill, Karthala

\section{Printed version}

Date of publication: 30 June 2008

Number of pages: $77-95$

ISSN: 1257-0273

\section{Electronic reference}

Susana Pereira Bastos, « Ambivalence and Phantasm in the Portuguese Colonial Discursive

Production on Indians (Mozambique) », Lusotopie [Online], XV(1) | 2008, Online since 08 March 2016, connection on 22 April 2019. URL : http://journals.openedition.org/lusotopie/781 


\section{AMBIVALENGE AND PHANTASM IN THE PORTUGUESE GOLONIAL DISGURSIVE PRODUGTION ON INDIANS (MOZAMBIQUE)}

Based on a number of Portuguese colonial discourses on the subject of Indian residents of Mozambique and a collection of discourses produced by the leaders of Indian communities upon their colonial "hosts", we will attempt to show how the absence of a joint encompassing representation of colonial society on the part of many Portuguese whites made the basis of their power seem uncertain and vulnerable. This uncertainty - worsened by a structural doubt regarding the value of the Indian way of thinking and acting - stimulated a process of paranoidization. Especially in the final years of Salazar's regime, this discursive denial of reciprocity competed with an alternative model of representation of colonial society, characterised by a repetitive use of micro-familial positions in the conceptualization of Imperial encounters. However, this model cannot be discounted as an autistic production of colonial power, mirrored by certain social groups, namely, the leaders of the main Indian communities. We will accordingly explore the hypothesis of a co-authorship, both in the gradual recognition of mutual relations between the Portuguese and Indians, and in the emergence of the familybased model of colonial relations itself.

\section{Ambivalence et fantasme dans la production discursive coloniale portugaise} sur les Indiens (Mozambique)

À partir d'un certain nombre de discours coloniaux portugais relatifs aux Indiens habitant au Mozambique, et d'un recueil de discours par les chefs des communautés indiennes et concernant leurs "hôtes » coloniaux, l'article s'efforce de montrer comment l'absence d'une représentation globale commune de la société coloniale parmi de nombreux Portugais blancs a fait paraître incertaine et vulnérable la base de leur pouvoir. Cette incertitude - aggravée par un doute structurel concernant la valeur du mode indien de pensée et d'action - a favorisé un processus de paranoïa. En particulier au cours des dernières années du régime de Salazar, cette négation discursive de la réciprocité s'est trouvée en concurrence avec un autre modèle de représentation de la société coloniale, caractérisé par une utilisation répétée des positions microfamiliales dans la conceptualisation des rencontres impériales. Toutefois, ce modèle ne peut pas être rejeté comme une production autiste du pouvoir colonial, reflétée par certains groupes sociaux, spécifiquement les chefs des principales communautés indiennes. L'article explore donc l'hypothèse d'une origine commune, à la fois dans la reconnaissance progressive des relations réciproques entre Portugais et Indiens et dans l'émergence du modèle même des relations coloniales fondé sur la famille.

\section{Ambivalência e fantasma na produção discursiva colonial portuguesa sobre os Indianos (Moçambique)}

Tendo por base um certo número de discursos coloniais portugueses sobre o tema dos habitantes indianos de Moçambique e uma colectânea de discursos apresentados pelos líderes das comunidades indianas relativamente aos seus « anfitriões » coloniais, o artigo tenta mostrar como a ausência de uma representação global 
comum da sociedade colonial entre muitos portugueses brancos fez com que a base do seu poder parecesse incerta e vulnerável. Esta incerteza - agravada por uma dúvida estrutural relativa ao valor da maneira indiana de pensar e de agir estimulou um processo de paranóia. Especialmente no final do regime salazarista, esta negação discursiva da reciprocidade esteve em concorrência com um modelo alternativo de representação da sociedade colonial, caracterizada pela utilização repetitiva de posições micro-familiares na conceptualização dos encontros imperiais. No entanto, este modelo não pode ser rejeitado como uma produção autista do poder colonial, reflectido por certos grupos sociais, nomeadamente os líderes das principais comunidades indianas. $\mathrm{O}$ artigo, por conseguinte, explora a hipótese de uma origem comum, ao mesmo tempo no reconhecimento gradual das relações mútuas entre os portugueses e os indianos, e na emergência de um modelo de relações coloniais ele próprio baseado na família.

\section{Cosden and Knowles define the dominant colonial mode of representation of

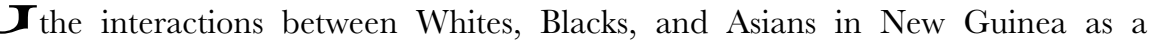 "colonial culture in denial". These authors argue that}

"all members of society were linked by continuous social relations [...]. But on the level of representations, the constancy of these social links, the dependencies they set up for all parties involved, and the true nature of power within these relationships was not acknowledged [...], especially on the part of Whites" (2001: 10).

Rosales (2006: 264-5) maintains that such denial of the stimulus values of daily interactions and exchanges between different social groups (racial, socio-economic, ethno-religious, etc.) and the consequent lack of a joint encompassing representation also seems to be a characteristic of the postcolonial narratives produced by a number of White Portuguese high-middle class families who lived in Mozambique for several generations in the colonial period.

Within a representational framework of the Mozambican colonial reality as an ethnically fractured and stratified society, relations with 'Indians' are excessively denied. The emphasis laid by those families upon their separateness from the rest of colonial society (condensed in the oft-repeated expression "não nos dávamos" ["we didn't mix"]) is matched by a narrative production characterised by "misinformation, the expression of a certain ignorance", that tends to represent the category 'Indian' mainly in terms of quantity and Otherness - "there were many Indians, many Indians", "they were very different", "all shop owners", "there were many in clerical services", "their celebrations" and "the saris their women wore " (Rosales 2006: 247-49). Moreover, the same narratives do not emphasize any recognizable form of dependency on the Indian population, or situations in which Indians could be conceived as having a real or imagined power over the speakers.

"The domination of the white stratum was a given" constitutes another major statement of Indian postcolonial narratives about colonial society in Mozambique ${ }^{1}$.

1 The pay gap between the salaries of specialized professionals varied depending on race (Indian or White), the exclusion of small and medium entrepreneurs from the industrial sector on the grounds of skin colour (only partially reversed since the beginning of the Seventies), the many restrictions to the employment of Indians in banks and the civil service (mitigated in the Sixties), the discrimination in access to education and academic evaluations, the racist practices 
Contesting the model of a colonial culture in denial however, Indian narratives focus upon the frequent commercial relations between Indians and Portuguese, and especially those established on the basis of mutual trust; from the colonial school system (where some interviewees felt discriminated) they recalled "Indian, Portuguese, black and mulatto boys playing together"; similarly, the way in which some restrictions in the industrial sector were overcome is recalled through statements such as "I found a Portuguese partner, and that's how I managed to set my first factory"; during the military service, several interviewees actually assert "I met Portuguese who were not racists, even officers"; at the interpersonal level, their narratives are more unanimous, and emphasize that "there was a lot of personal interaction between Indians and Portuguese" and also that (in particular, in comparison with direct experience, or that of relatives and co-ethnics in the neighbouring territories) "the friendship of the Portuguese was very different from that proffered by the British" or, more directly, "friendships such as ours were not possible in Uganda, Kenya, and much less so in Rhodesia and South Africa" (Bastos \& Bastos 2005, 2006).

The latter narratives, much as those which deny any reciprocity, point us towards identity economies that cannot be fully explored in a short article. We will attempt to analyse latencies and the unsaid in the discourses produced by both groups of interviewees, while keeping in mind the interaction of different postcolonial experiences in the reconstruction of colonial relations, but also avoiding the simplistic reductivism of the aforementioned colonial memories to a simple postcolonial 'effect'.

Based on a number of Portuguese colonial discourses on the subject of Indian residents of Mozambique and a collection of discourses produced by the leaders of Indian communities upon their 'hosts', we will attempt to show how the absence of a discourse of mutuality on the part of many Portuguese whites made the basis of their power seem uncertain and vulnerable. This uncertainty - worsened by a constant suspicion of Indian double vision and, consequently, a structural doubt regarding the value of the Indian way of thinking and acting - stimulated a process of paranoidization (Bhabha 1994: 101), more or less intense but non-homogeneous.

Despite this, the discursive denial of reciprocity competed with an alternative model of representation of colonial society, especially in the final years of Salazar's regime. This model was characterized by a repetitive use of micro-familial positions in the conceptualization of Imperial encounters. In Salazar's own words, the Portuguese Empire was a 'house', and a 'home', in which the Portuguese (including the 'natives') were a 'family'4 and each overseas colony/province reproduced the same house/home/family/fatherland, "soul and blood, like a mother and her

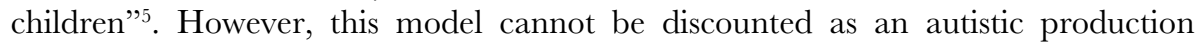

during military service, the impossibility of renting or buying houses in certain urban spaces, etc., appear constantly in recorded memories. Regardless, the majority of informants spontaneously declared that Mozambique did not experience apartheid, like South Africa and Rhodesia.

2 Salazar, s/d: 162.

3 SAlazar, 1937: xi and s/d: 376.

${ }^{4}$ Salazar, 1951: 451, 463-4.

${ }^{5}$ Speech by António de Oliveira Salazar to the Assembleia Nacional on 9 October 1939, SalazAR, s/d: 178-179. 
of colonial power, mirrored by certain social groups, namely, the leaders of the main Indian communities. We will accordingly explore the hypothesis of a coauthorship, both in the gradual recognition of mutual relations between the Portuguese and Indians, and in the emergence of the family-based model of colonial relations itself.

\section{Denying hostility towards Indo-British immigration while opposing the internal (economic) enemy ${ }^{6}$}

In 1932, the Government of Mozambique established rules limiting the employment of foreigners in the colony, citing the 'unemployment crisis'. According to Diploma $^{7}$, in all firms and commercial, agricultural, and industrial companies, as well as other individual or collective enterprises, at least $70 \%$ of the non-indigenous population had to hold the Portuguese nationality.

In a period of commercial hardship, Indo-British firms could have hardly hired such a high number of Portuguese nationals. For example, an average-sized urban firm, with an owner/manager and four employees, all of them Indo-British and with less than five years of residence in Mozambique, would have had either to contract 11 additional Portuguese employees (a total of 16 workers, 30\% foreign and $70 \%$ Portuguese), or to dismiss part of its British employees, and contract the required number of Portuguese nationals.

The position of the small Indian cantineiro was also threatened. If he employed a British Indian assistant, he would also be obliged to hire two Portuguese citizens. In view of the small size of the average Indian establishment, where it had often been the custom for one member of a family to assist another, he would be driven out of business. To make matters worse, Portuguese authorities began to issue rigid interpretations of the Decree, whereby underage apprentices who worked for member of their families and/or co-ethnics were counted as employees.

Moreover, the British Indians who left Mozambique could not return, unless they could prove that they came to resume the same employment or position held when they left the country. They were also forced to undergo complicated and costly bureaucratic procedures.

The Portuguese government answered the repeated notes of the British Embassy by reiterating that abrogation of the aforementioned measures was impossible, and insisting that these restrictions were indeed not a manifestation of a "hostile intention towards the Indo-British". However, a report of 1938 (subsequently censored), which the Portuguese Foreign Minister had attached to his answer to the British

${ }^{6}$ This chapter has already been published in a very different paper (Bastos 2005) in which we tried to articulate the processes of transnational connection and reterritorialization of IndoGujarat migrants settled in Mozambique, analysing them as the result of an interaction between socio-familiar resources and colonial and postcolonial constraints (S. BAstos 2005).

7 Diploma, Boletim Oficial de Moçambique, Imprensa national de Moçambique, 23 Julho de 1932.

${ }^{8}$ Cf. Communication sent by the Portuguese Foreign Minister to the British Ambassador, 8 July 1938. 
Embassy, reveals the hidden reasons behind the measures for the regulation of employment and mobility of foreigners. It stated "the economic opposition to Indo-British immigration" based upon the "reduction of the advantages [resulting from "exceptional conditions of religion, adaptation and habits"] in economic competition, attempted in particular to increase expenditure and decrease profit in gold, by all legal means",

Since political pressure was producing no result, the Indo-British began implementing measures to circumvent the legislation. A number of the largest firms included among partners not only close family members (brothers, cousins, brothers-in-law, etc.), but, with tiny percentages, their most trusted employees, usually distant family members; as foreign partners, these did not count as employees. This strategy, widely adopted, led in 1948 to the publication of a dispatch, which specified that all partners in a firm who had a position therein, including that of manager, were indeed to be counted as employees. Simultaneously, a number of medium-sized and large firms also employed (but never in top positions) Indians of Indo-Portuguese origin (from Diu and Daman) ${ }^{10}$. However, during the Second World War and until 1948, the application of legislation on the employment and mobility of foreigners was less rigorous. This, together with numerous forms of bribery to inspectors, made it possible for small, medium-sized, and large Indian firms to avoid observing the prescribed percentage of Portuguese employees.

The restrictions and formalities required for entering and returning to Mozambique were more difficult to circumvent. Indo-British subjects therefore began to modify their circulation practices. The pattern of male migration (whereby wife and children remained in the sending country, and were regularly visited by the head of the family) was progressively abandoned ${ }^{11}$ and the number of marriages among couples born and resident in Mozambique began to increase. The process of familiar reunification and reterritorialisation contributed to increase not only economic, but also sentimental and identity investment in Mozambique, while ties to the sending countries were also maintained.

\section{"Working hand in hand, shoulders touching, for the benefit of the same mother country..." - Emphasising fraternal reciprocity}

The main Indian leaders, in part as a reaction to the hostile economic measures against Indo-British subjects, became involved in the production of a set of discourses upon their 'hosts'. For example, at the inauguration of the Veda Mandir in Lourenço Marques, Bhagwangi Kakoobhai thus spoke to the Deputy Governor, who had been invited:

9 Information of the Direção Geral da Administração Politica e Civil, 24 May 1938.

10 Since the second half of the 19th Century, Hindus from Diu and Sunnis from Daman began to migrate to Mozambique. Most came to work as masons in the construction of colonial infrastructures (BAstos 2005).

11 Indo-Portuguese citizens (both Hindus and Sunnis) maintained both the connections to their sending countries and the pattern of male migration for a longer time, since they were exempt from the legislation. 
"We, Hindus, see the Portuguese as the most welcoming of all the lords of Earth. They received us with friendship, putting means of work and richness at our disposal; and with wise, humane and civilised laws, they protected us under their flag, as equals of every other man; and with a spirit of tolerance never before seen they respected the customs and religion of the Indian people, without enquiring as to their variety or status. For all these reasons, we are grateful for Portuguese hospitality [...]."12

A few years later, His Highness the Aga Khan was 'triumphantly' received in Lourenço Marques (thus somehow outshining the visit to the North of the country of then-Portuguese Minister for the Colonies, Marcelo Caetano). His first words on 'Portuguese soil' echo those of Kakoobhai: "The hospitable reception I have just enjoyed is a clear manifestation of the Portuguese spirit". In the gala session at the Ateneu Grego and the 'sumptuous banquet' at Casino Costa organised by the Ismaili centre and the Mohammedan Community, "the illustrious descendant of the Prophet Mohammed" emphasised that "socially and economically, the Indians the Portuguese, hand in hand, have made a larger Portugal of Mozambique", thus addressing a farman to all Indians in the colony:

"[...] especially the Indians who were born on this soil, must be Portuguese first, and only then Indian, because they must all recognise the equal treatment offered by the Portuguese Empire to all those who work in Mozambique."13

A few months later, in the elegant Caravela tearoom, before over 150 guests from various Indian, Portuguese, and European firms, government members, and also prominent traders from the South African Union, who had come together in homage to Karim Ayob, Jossub Hajee Suleman Ebrahim and Abdool Dada Osman, echoed:

"This colony has been an oasis, where Hindustanis have worked for two centuries [...], engaging in their activities hand in hand, shoulders touching with the Portuguese, free of persecution, despite their different beliefs, customs, and traditions. They then asked all Indians to 'work for the prosperity of Mozambique', 'where they live under the protection of the Flag of the Portuguese Republic, with no discrimination', and emphasised that, 'while helping their distant families, they must leave in Mozambique what they have earned in Mozambique." "14

On a preliminary level of interpretation, these discourses validated the maxim of Portuguese colonial 'tolerance', both in the "economic area and in the cultural and religious sphere" 15 ; they could actually be interpreted as anticipating the later expression of "an equalitarian life [...] absolutely foreign to the idea of conflict and domination, to the feeling of racial superiority or inferiority" "16 which made the Portuguese Empire unique and superior to other colonial models. Despite this, they also attempted to remove any paranoia projected upon Indian immigrants,

\footnotetext{
12 Speech by Bhagwangi Kakoobhai, leader of the Indian Community (Bharat Samaj) at the inauguration of the Veda Mandir [temple], in 'Iniciativa da Comunidade Indiana', 1938.

13 Lourenço Marques Guardian, 2 August 1945.

14 Lourenço Marques Guardian, 2 October 1946.

15 Speech of the ad interim Governor General on 31 July 1938.

16 A. Moreira, 1963.
} 
inverting the idea of the opportunistic and instrumental migrant, faithful to his origins, enclosed in his religious community, with no feelings of identification, loyalty and gratitude towards their host society. On a subtler, hidden level, they stimulated the family-based fantasies of their hosts, by emphasising the fraternal friendship and cooperation that linked Indians and Portuguese, since the remote past, for the benefit of the same Portuguese mother country.

Such discourses did not neutralise the paranoid attitude; however, they did demand an official response, frequently transmitted through the colonial press. At this level at least, the Indians of Mozambique began to be lauded for their "ordered, respectful and devoted to work" posture, for their "correctness of behaviour", for the "honesty shown in the exercise of their professions and trades", for their worth towards the development of the colony, for their "submission to Portuguese laws". Due to the multiple "proof" of gratitude and political subordination that they offered they "undoubtedly deserved public consideration" and were even considered "close co-operators in the work of aggrandisement" of that "corner of the Portuguese Colonial Empire" 17 .

\section{The construction of a rival power: 'Mohammedan hegemony' as a threat to Portuguese sovereignty}

The category 'Indian' frequently integrated both Hindus and Muslims. However, a clear distinction was made in the colonial discursive production upon relations between Indians and Africans. The religious system of Hindus was perceived as "similar to that of the natives [...] the sacred is overlaid upon the supernatural in every aspect of life" ${ }^{18}$; however, they were defined as having little influence over the native population, since they had no missionary inclinations ${ }^{19}$. Moreover, they never religiously adopted their mixed children who, "usually, they baptise as Muslims", because "a mixed child of a Hindu and a woman of another race could never participate in the ancestor cults and belong to his father's caste" 20 .

In contrast, the 'Mohammedan' Indians, associated with a religion which allowed polygyny and encouraged religious conversion, were defined by their ability to

${ }^{17}$ Speech of the Deputy Governor General, Dr. Nunes de Oliveira, at the inauguration of the Veda Mandir in Lourenço Marques on 31 July 1938, in "Iniciativa da Comunidade Indiana", Lourenço Marques Guardian, 2 August 1938.

${ }^{18}$ Estudo sobre Indianos: 27. Estudo sobre Indianos, commissioned by the Provincial Government by the Ministry for Overseas Territories, on the 10 May 1961, Arquivo Histórico de Moçambique, Maputo. His autor was António Maria de Matos, a civil servant of the then Direç̧ão dos Serviços da Economia em Moçambique.

19 A.J. Dias 1956: 11.

${ }^{20}$ Estudo sobre Indianos, op. cit:: 27. Despite the fact they thwarted the colonial desire for symbiosis, their irreducible and impermeable power of identity was seen as compatible with Christian moral and religion. According to Estudo sobre Indianos (op. cit.: 27), Hindu impermeability to "whatsoever identification [...] with any other social group" was selected as the main cause for the "tranquil serenity with which $[\ldots]$ they encourage and help their children to attend in $[\ldots]$ secondary schools classes of Christian morals and religion, without this having the slightest effect on the ritual organisation of their private lives and the realisation of the Dharma". 
integrate their mixed-race children and obtain converts among the black population. The 1940 census recorded 8,754 Muslims among the 'non-indigenous' population, of which 5,216 were 'mixed-race' (59.6\%) and 217 (4.1\%) 'African'; while, among the 2,938 Hindus, only just 159 were 'mixed-race' $(5.4 \%)$ and $13(0.4 \%)$ 'African'. As Zamparoni concludes, "even if the large Islamised population in the Northern coastal area of the colony, which was considered 'indigenous', was not included, Africans (mixed and blacks) would still account for two thirds of Muslim believers" (2000: 214). It is within this context that, unlike Hindus, British-Indian Muslims, and in particular the large importers/exporters/warehouse owners and traders of the Northern coastal area of the colony began to be described by the colonial administration as active agents in the attraction and conversion of Africans to Islam and, as a corollary, as potential enemies of Catholicism and the expansion of Portuguese authority.

This colonial representation of the Muslim gradually acquired a political dimension. The religious attraction of the 'indigenous population' was increasingly read as a means to political recruitment against colonial authorities, and as such, required the implementation of measures restricting religious conversion. For example, in 1937, in the North of Mozambique, the Portuguese authorities found a number of Ethiopian posters calling for popular resistance against the recent (1936) invasion and establishment of colonial domination of that territory by the Italians. They had supposedly entered Mozambique through trade routes controlled by Muslims, and the episode led to the closure of a number of mosques (in Porto Amélia, Ibo, Mocimboa da Praia and Pemba), which were only reopened the following year, on condition that they may only be used by Muslims of Indian origin (Alpers 1999: 166-7).

During the following decades, the impact of Islamic radio broadcasts (for instance, on Radio Cairo) in support of independence movements in Sub-Saharan Africa, which were very popular in the North of Mozambique, and the political propaganda sent from Egypt itself to Muslim associations, together with the slogan that Islam is the religion of the coloured man, while Christianity is the religion of the white $\operatorname{man}^{21}$ strengthened the construction of South-Asian Muslims as potential bearers of anti-Portuguese ideologies.

In this discursive context, Jorge Dias, the main figure in Portuguese anthropology at the time and the author of one of the first reports on ethnic minorities in Portuguese overseas territories, construed the "Mohammedan Indians" of Mozambique as "a grave threat to Portuguese sovereignty":

"Undoubtedly, the current expansion of Islamism [...] is the struggle for Mohammedan hegemony. The propaganda sent from Egypt to African associations or societies in the province of Mozambique [...] is unequivocal proof of their ambition towards political domination". ${ }^{22}$

To justify this situation, Dias recalled the role of Cairo (and of El Azhar University) as a "pole of the Islamic world", but also of internal variables, specific to the situation in Mozambique. Firstly, the "polygynous tradition" and the ease of inte-

21 Dias, op. cit.: 1 .

22 Ibid.: 1. 
gration of the "mixed-race element" observed in the "Mohammedan" ethnic minority, together with the means of life of many of its elements ("commerce in the bush"), offered constant opportunities for contact with the "natives", and kept them from "association" with the Portuguese. And if all this was not enough, Muslims displayed a strong missionary activity "with political elements thrown in" (in particular among those who had recently acquired the Pakistani nationality) that went against not only "the effort towards assimilation of the natives" made by the Portuguese, and the very conception of the Portuguese Empire as tolerant and multiracial.

"In their general stores in the bush [...] they eat at the same table as black converts, because their religion makes no difference between men. [...]. The barrier they attempt to create between the two religions, associating each one with a pseudo-racial group white and coloured (black) - is highly dangerous and may have dire consequences if it keeps advancing". ${ }^{23}$

\section{"Such was the power of dada..." - Contesting the political ambition of Indian power}

The exploration of the colonial construction of the Mohammedan Indians of Mozambique as "a grave threat to Portuguese sovereignty" with the aid of a number of elderly leaders of the Indian communities yielded significant results in two fields. On the one hand, many recognised that Indians, especially in rural areas, could easily be perceived by colonial authorities as a form of counter-power. A "power" that could be read as the product of "an orientation, a willingness to engage with the other" (Hannerz 1996: 103); a "power" of understanding of the world as lived by others, a power of translation (between languages, including those of natives and colonisers), and improvisation (using the language of the other); but also of a power of transformation of oneself and the other (van der Veer 2001).

"I met an Indian Muslim on the beach of Manica who lived in a village near ours. I called him dada [paternal grandfather]. He had been a hunter of elephants, and all the Africans thought he had great magical powers. [...] To the African, a man who goes into the jungle, kills elephants, sleeps in the jungle, and is not attacked by wild beasts, had to be a powerful man. One day, I asked him, 'Where does this idea about your power come from, dada?' And he answered me, 'My power is my gun, which I always keep at my side'. Another time, I found him at his house, sitting on the floor in front of a trunk. The number of Africans who went to visit him struck me. They spoke to each other and then each of them left some money on top of the trunk. When this ended, I asked him, 'Dada, what are they doing?' And he said, 'All these men who come here, they are witch doctors. They are asking me to protect them from other witch doctors. They believe that only I can protect them. And this is why they give me money. If they didn't, they wouldn't feel protected.' I saw this, otherwise I wouldn't have believed it. Such power the Indians had in Mozambique, see! Their reputation was such that even the governor had to have good relations with him, if he wanted to stay there. They even say that once he had a heated discussion with 
the governor, and all the Africans turned against the latter, and he had to be transferred. Such was the power of dada." ${ }^{24}$

Nonetheless, they disavowed any ambition to transform this power into an organised political project. All the interviewees describe the majority of Mozambican Indians (Hindus and Muslims) as "complying with the regime" (they even named a number of well-known collaborators who aided PIDE, the regime's political police), or even totally extraneous to political issues. According to them, this "refusal to get mixed up in politics" was the result of a higher investment (passed down through the generations) in religion, family life, and the "family business" which alienated "the younger generation from what goes on around them in Portugal and the World"; or the product of a quasi-magical belief "that things would not change in Mozambique" (because they wished it so). Especially after 1961, a different hypothesis put forth was that such refusal was a defensive strategy "to avoid being expelled" ( $c f$. the following section). Moreover, a number of narratives emphasised that secondary and university-level education, as well as a longer permanence of both family and community, were prerequisites of an awakening to political causes and activism. Contact with Indian associations that, merging their political interests with those of the Africans, opposed many forms of economic, political, social and racial inequality in the East African colonial system during the Thirties and Forties, or active participation in student movements of the late Sixties in Portugal determined subsequent political activism. "Mohammedan ambition towards political domination" never belonged in the world of these speakers, nor in that of several other Indian interlocutors linked to anti-colonial resistance.

"In my family, and even within the community, I never heard one political discussion. Indians did not concern themselves with such issues. They wanted, they were convinced that things would continue as they were in Mozambique. They were no fools. They were able to gauge situations, face crises, some even ran great risks. If they thought that in the near future things would have to change, they would not have sunk so much money in Africa. [...]. But I always had a great interest in politics. So many times my father said, 'If you want to be a politician, go to India, but not in Africa'. You know, I always was very Mozambican, despite the fact that I worked with and had many friends among the colonials. But I was an exception. [...] And concerning that, using religion for anticolonial propaganda, I never heard about it. Much to the contrary. You know, Muslims are very caught up in religion, and this contributes to their being generally uninformed about politics, they don't want to know. In the past, just like today. But to me, religion is my faith, it helps me emotionally, it does not blind me. [...] After independence, I became actively involved with Frelimo ${ }^{25} .{ }^{, 26}$

"In colonial times, the typical Indian, Hindu or Muslim, began by spending 4 or 5 years behind a counter, as a shop assistant, then started his own business, sometimes with the help of his boss. He sent for his brothers and sons, to work with him. Indians were like this, only trusting their relatives and even keeping their sons from studying. Ten years old, and they became employed in commerce. They were only interested in their businesses, their families, and their religion. If they read at all, it was the first

${ }^{24}$ Dr. M. Jassat, born in Mozambique, lawyer.

${ }^{25}$ Frelimo: Frente de Libertação de Moçambique, Mozambique Liberation Front.

${ }^{26}$ Amad, born in Mozambique, retired shopkeeper. 
page of a newspaper. As a rule, they took no interest in politics. The few I met that did, two or three [...], belonged to families who, in the Sixties, sent their sons to university in Portugal. [...] None of us, girls included, were stopped by my father, but that was extremely uncommon. [...]. I went to Lisbon in 1969. I followed student movements. At the time, the colonial war issue was very important, and some already spoke of the independence of colonies. I met Ferro Rodrigues and this opened up my horizons, and set me apart from the Indians I knew in Mozambique. [...] In 1973, I escaped to Sweden, and that was the first step towards engagement with Frelimo." ${ }^{27}$

Such an affirmation of 'lack of interest' in political issues on the part of Indians, upheld by several colonial sources, was however problematic. The non-exteriorization of the Indian way of feeling or thinking, associated to a notable ability to deceive and fool the colonizer on any ideological plane, fed the 'doubt' upon the value (real or speculative and potentially insurgent) of their political convictions.

"They appear to accept the opinion of the [Portuguese] interlocutor, even though they have one that is very well structured and absolutely to the contrary. They do not become exalted and, if anyone should try to change their opinion, either they uphold their polite and smiling rejection, or appear to accept the new idea with no enthusiasm, leaving their interlocutor to doubt whether they really did adopt it with conviction or otherwise." ${ }^{28}$

\section{Reconstructions of the internal 'enemy': Hindu Nationalism as a threat to Imperial sovereignty}

Under pressure by certain sectors of the Portuguese population who wished to "see the internment and expulsion of all those who, independently of their nationality" were "known as monhés" 29 , the then Governor General of Mozambique determined, a few days before the "attack on Goa" by the Indian Union, that "measures should be taken to avoid that the lives and assets" of Hindustani citizens "suffer any damage". He therefore ordered their "internment", "the closure of their commercial enterprises and private residences", as well as the prohibition to issue any entry or exit visa to Hindustanis ${ }^{30}$.

Shortly after the invasion of Goa, Daman and Diu, according to a statement attributed to the Portuguese Foreign Office, the detention of Indians of Indian nationality in Mozambique - who were unofficially estimated to be about 12,000 was due to the fact that Portugal planned to free them in exchange for the liberation and repatriation of approximately 3,200 Portuguese captured in Goa by Indian occupying forces ${ }^{31}$.

${ }^{27}$ Dr. Ratilal, born in Mozambique, economist.

${ }^{28}$ Statement given by the General and Commanding Officer of the 4th Military Region of the colony, in the late 1950s.

${ }^{29}$ Arquivo Nacional/Torre do Tombo (ANTT), Polícia Internacional e de Defesa do Estado (PIDE), Lisbon, Official letter of the sub-Director of PIDE, 26 December 1961, sent to the General Director of the same organisation.

30 Ibid.

${ }^{31}$ ANTT, Telegram from the Foreign Office to the Embassy of Egypt. 
Whether it could be seen as a measure for the protection of Indians and of public order, a means to guarantee the liberation of the Portuguese in Goa, or as a retaliatory political measure, detention (and subsequent expulsion) particularly targeted Hindu settlers in Mozambique, among whom the Indian nationality was most widespread.

Until the independence of the Indian Union, all non-Portuguese Indians were considered British subjects, and they were issued documents accordingly. When the Indian Union and Pakistan became independent, they were encouraged to choose between obtaining documents as citizens of either state. A significant percentage of Muslims acquired the Pakistani nationality, and most Hindus chose India. However, a number of Indians kept their British nationality, usually large import/export operators and the official exchange agents of the regime. Lastly, a relatively high percentage of their children, who were born in Mozambique, were registered as Portuguese independently of their parents' nationality.

On the other hand, in the late Fifties and in the period immediately after the invasion of Goa, many Muslims with Indian passports accelerated the processes towards Pakistani naturalisation, since this would be the only nationality that would enable them to obtain residence permits on Portuguese soil. The political alliance between Pakistan and Portugal meant that the majority of Pakistani nationals were not hit by the measures of detention, winding up of assets and expulsion. Neither were the Ismailis, "in their majority not naturalised" as Portuguese ("despite their insistent desire to do so, in particular after the partition between Pakistan and Hindustan" 32 ) and protected from any retaliatory measure by the relations between their leader, the Aga Khan, and the Portuguese government.

\section{Belief in the political innocence of resident Hindus or protection of the colonial economy? The official recognition of reciprocity (against certain white opinions)}

In his hesitation between the desire to avenge the dishonour suffered by the Empire and to protect the national economy, the paranoidisation of Hindus as 'enemies' of national interest and the belief in their innocence, the Governor General of Mozambique opted for a compromise solution. A significant number of Hindustani nationals were indeed expelled (to appease public opinion), while the Hindu elites with whom Portuguese authority had been maintaining relations of mutual support (economic and political) for years, were protected. Despite a number of disparaging comments expressed by smaller and medium-sized Portuguese traders, large import/export Hindu firms were therefore not closed, namely those belonging to Haridas Damodar Anandji and Dayaram Gopaldas (in the Beira region), and to K.B. Kakobhai (in the capital, Lourenço Marques) ${ }^{33}$. Moreover, entry and exit visas were indeed granted, even at the most delicate of times, to these businessmen and their families ${ }^{34}$. Lastly, the orders for the expulsion of dozens of managers

32 Estudo sobre Indianos, op. cit:: 16.

33 Cf. In particular "Os funcionários fecharam as firmas indianas em Moçambique", Rand Daily Mail, 13 January 1962.

34 ANTT, PIDE, Official letter of the sub-Director of PIDE, 26 December 1961. 
and sub-managers of firms of privileged Hindustanis (in Porto Amélia, Quelimane, Nampula, António Enes, Nacala, Lourenço Marques, Beira, etc.) were annulled, since their departure would make "the operation of firms essential to provincial interests" 35 impossible.

The colonial decision to uphold the relationship with British Hindu elites did not go unnoticed. This resulted in repeated justifications in reports and official communications to the effect that the goal of numerous residence permits granted to Indians was "by no means to protect the interests of the aforementioned firms, or of Hindustani subjects - but rather, to protect our national economy" 36 .

Accordingly, in the following decades, there was no systematic attempt to paranoidise those Hindus who were allowed to settle in Mozambique. An exception however deserves to be mentioned. Simultaneous to the beginning of the struggle led by the Armed Forces against Mozambican 'liberation movements' a 'movement among Hindus' was occasionally noted,

"whose aim is to avoid that the individuals who are of draft age be called to active service. In the event of any 'Hindu' being drafted, he will receive instructions to avoid taking an active part in the combat the Portuguese are waging against Mozambican 'nationalists'; to the contrary, they are instructed to attempt to cooperate with the 'liberation movement' [...], demoralise the troops, especially the Africans, [...] and gather as much information as possible, to be transmitted outside the country, where the leaders of the 'liberation movement' act." ${ }^{, 37}$

The same source however immediately indicated that the real threat was not to be found among resident Hindus. The aforementioned instructions "were given by those 'Hindus' who had been expelled, [...] many of whom had settled in Kenya and Tanganyika, where they were possibly contacted by Mozambican 'nationalist' leaders". ${ }^{38}$ The source also added that this anti-colonial "propaganda action" was mainly justified by the a-political desire for family reunion, of two different generations, in a territory endowed with identity reference ${ }^{39}$.

\section{Reconstructions of the internal 'enemy': the symbiosis between Islam, tribalism and witchcraft}

The attempts by the Pakistanis to set themselves apart from the Bharatis (Hindus) as hostility grew between Portugal and the Indian Union, and the explicit support

35 See the official letters of the Comissão Coordenadora dos Assuntos Relativos a Pessoas e Bens dos Subditos da União Indiana [Coordinating Committee on Issues Regarding Subjects of the Indian Union and Their Assets] to PIDE (ANTT), which suspended the order of expulsion from the province of numerous Hindustani managers and sub-managers between 1961 and 1963.

36 ANTT, PIDE, Official letter of the aforementioned Coordinating Committee to PIDE, 14 January 1963.

37 ANTT, PIDE, Information of the Mozambican Governor General's Office to the Director of PIDE, 3 March 1965.

38 Ibid.

39 Ibid. 
given to the Portuguese against the Indian Union $^{40}$ did not introduce a radical change in the colonial discourse on Muslims. To the contrary, the connection between Islam and 'subversion' intensified after the onset of armed conflict.

A confidential PIDE report of 1967 upon the "subversive situation" in Cabo Delgado and Niassa confirmed the "support given to subversion by high Islamic dignitaries", stating that their action, and that of Islamised elements, had been "revealed as clearly pernicious". In its analysis of the reasons that turned Islam into a political 'weapon' against Portuguese authority in Mozambique, the same source mentioned: the existence of doctrinal passages that encouraged the use of Islam for "political ends", namely those that condemned "racial discrimination", and replaced "social hierarchies based upon ethnic concepts with those based upon Muslim supremacy"; the gradual implementation of "progressive currents" (emanating from the small ports of Tanganyika, Northern Mozambique and Zanzibar), through the dissemination of the Peking Koran, which called for the "preaching of the Marxist doctrine, stressing the danger of the 'white man's god' and highlighting Afro-Asian solidarity", and of the Lamu and Mogadishu Koran, which in opposition to the former, envisaged that "Africa would belong to Africans, and not to the Arab and Islamic world, as soon as the Redeemer would come"; the existence of a "rather fluid [...] Islamic hierarchy [...] guarantees a considerable autonomy, and therefore the chance to conceal subversion"; and, moreover, the existence of "ideal conditions" for the symbiosis between Islam, tribalism and witchcraft ${ }^{41}$.

The connection between witchcraft and subversion deserves some attention, since it was frequently recalled by governmental discourse. As is widely known, since the early twentieth century, the colonial regime attempted to destroy traditional power structures, hence creating the figures of the régulo and the nduma, and repressing rituals of worship of ancestral spirits, as well as stripping of authority the religious leaders (diviners, healers, mediums, etc., but also leaders of independent churches), and all those who were locally invested of obscure powers (witches, for example). The aim of the regime was not merely to eliminate the power of traditional political authorities, but also to repress the exercise of symbolic power mobilised by certain local leaders, thus questioning the very source of legitimisation of both powers, namely, ancestral spirits, who had a central role in the daily lives of the natives. This was a task that the colonial authorities soon recognised as vain, and which led them to accept native performances of worship, appeasement and search for protection of and from ancestral spirits, as long as these did not appear as threats or strategies of resistance to the colonial regime (which required the payment of prescribed taxes, and implemented a system of forced labour and work migration to South Africa, etc.). The authorities therefore slackened the repression of genealogical cults but continued to punish by law (see the

${ }^{40}$ For example, by hanging inside the homes posters depicting the flags of Portugal and Pakistan, and slogans such as 'Pakistan respects Portuguese hospitality', ANTT, PIDE, 15 December 1961.

${ }^{41}$ ANTT, Intelligence of the PIDE delegation in Mozambique, upon "The Religious Question in the Province: Islamism", 26 June 1967, sent to the Ministries of National Defence, Overseas, and the Foreign Office. 
Penal Code of 1964) the practice of witchcraft, thus clearly indicating what was the rival source of power which could threaten colonization (Honwana 1996).

Beginning in the Sixties, the information gathered by PIDE that possession, suggestion or hypnosis and witchcraft practices were carried out by "mualinos and chéchés [...] frequently and by accumulation, diviners, healers, and witches", as part of subversive actions ${ }^{42}$, could only reconfirm the colonial belief that the symbiosis between Islam and tribalism were a considerable counter-power.

\section{Official reconciliation: the quest for an alliance between Christians and Muslims}

Towards the end of the Sixties, colonial policies towards Muslims (of Indian origin as well as the Islamised populations of Northern Mozambique) underwent a change (Monteiro 1993, Cahen 2000), the "plan of psychological action towards the mobilisation of the Muslim masses" that included four phases "detection, attraction, affiliation and mobilisation". The detection phase began in 1965; it consisted in enquiries "towards the identification and characterisation, in view of the internal conflict (already under way), both internally and externally, of the leaders of the Muslim population in the whole Province." The phase of attraction began in 1967/1968, to show "that the authorities knew and respected Islam as a revealed religion"; "that the authorities wished to establish communication" and that they "controlled the means of communication" (and encouraging "the widest possible exchange", but with the intention and means to "prevent/repress"; and that "the authorities wished to preserve the culture of Muslims" (and control it, for example using Portuguese as the language for communication). The last two phases - affiliation and mobilisation - were destined to "associate all the main Islamic dignitaries of the Province with the Portuguese administration in active demonstration against subversion" ("thus drawing the populace") and to "actively involve the Islamised population in anti-subversive action" ${ }^{43}$.

While recognising its vulnerability, colonial power seems to have disinvested the desire to fight against the 'enemy'. Despite the fact that it was still detaining traditional Muslim authorities, xehes and mualinos, with the accusation of engaging in subversive activities, and occasionally, closing mosques ${ }^{44}$, it also attempted to 'communicate', and even to advance Islam, led by the ambition to control it (and even manipulate it in its favour) through alliance. The socio-economic and religious promotion of Islamic members of confrarias [brotherhoods] and of Islamised ethnic groups to avoid their turning to support Frelimo, the exploitation of ethnic and religious divisions and conflicts inherent to Mozambican Islam, the project of restoring Islamic teaching through the future creation of official schools (that is,

\footnotetext{
42 ANTT, PIDE Intelligence, 26 June 1967.

43 F.A. Monteiro, 1993a: 303-311.

44 'Resumo da evolução da situação nos países vizinhos e partidos emancipalistas e das actividades do inimigo' ['A summary of the evolution of the situation in neighbouring countries and independentist parties, and of enemy activity'], 1968, Supintrep, $\mathrm{n}^{\circ}$ 2, quoted in F. Garcia,
} 2001: 414. 
financed and controlled by the Portuguese state) to avoid the propagation of progressive movements, and the repeated attempts towards political recruitment in favour of the regime of the most influential Muslim individuals were examples of the new strategy.

\section{From 'enemies' to 'brothers': dreaming of the maternal power...}

Unlike Hindus, Muslims of Indian origin were not merely a religious minority. As such, they were repeatedly presented as a potential source of transmission of subversive ideas. The Portuguese colonial discoursive production on Muslims soon became impregnated by a conspiracy 'theory ${ }^{\prime 4}$, similarly to that produced in French territories south of the Sahara, British ones such as the Sudan and Nigeria, or those under British rule in East Africa. However, while the British administration did delegate local jurisdiction to Islamic authorities under their control (a form of government known as indirect rule) and the French administration followed the traditional centralized model and refused to delegate to any 'community', Portuguese colonial power in Mozambique (at least until the late Fifties) was characterized, according to several sources, by a mixture of "political alienation" and "administrative contradictions"

Especially since the Sixties, Portuguese colonial policies turned for inspiration to the initiatives of the British colonial powers in Kenya and Tanzania, towards

${ }^{45}$ The conspiracy theory was complicated by a third Indian power, one that despite its adherence to Islam was perceived as a supporter of Portuguese colonial power. Towards the end of the Forties, the colonial discourse clearly differentiated Ismailis from the other "Mohammedans". Seen as "almost indistinguishable from the participants in Western culture" Ismailis "willingly take part in the national style, adopting our ways and habits" and "being already integrated in all professional activities, as well as commerce, which is traditional"; among them, one could count "some of the most notable traders and industrialists of Mozambique". Moreover, their "rather extensive and politically significant network of external contacts", "offered [...] the Portuguese Nation the chance to use them as agents of understanding and peace, towards Tanganyika and Kenya, where their communities are so influent as to be able to obtain from future political leaders the guarantee of satisfactory political relations with Mozambique" (Estudo sobre Indianos, op. cit: : 16).

${ }^{46}$ For example, according to Estudo sobre Indianos, when Mozambican Muslims were "encouraged to build a national church, as it was imminent" the Portuguese state did not act opportunely. The "inaccurate interpretation or alienation of the political problem posed by Islamism" made it impossible "in the past, to take every possible advantage of the conflict then waging between the Muslim leader of North Mozambique and the sultan of Zanzibar." Other than the increasing implementation of the 'divide and rule' strategy, the colonial administration implemented contradictory measures. It repressed the most visible aspects of Islamic conversion (forbidding the establishment of new Islamic associations and places of worship), while simultaneously tolerating the invisible expansion of Islam among the natives. These contradictions had rather serious effects in the area of Mossuril, where "while the construction of new mosques was forbidden, in order not to be conspicuous, the leadership of the lay administrative territories (regulados), which was less conspicuous, went to Muslim chiefs. This happened with the Nasarais, traditionally insubordinate, and in the regulado of Corapira in the Monapo" (Estudo sobre Indianos, op. cit:: 18). 
the "encouragement of Islamic organisation", "in the attempt to [...] control it" Nevertheless, the Portuguese discourse of power based on alliance continued to be clearly distinct from the British one, mainly due to the way in which it acquired a religious and affective dimension mobilised by the construction of a "common maternal filiation" between Christian and Muslims.

The "brotherly letter" by the Bishop of Vila Cabral, Father Eurico Dias de Nogueira, to the Muslims of his diocese did begin with a reference to one of the 'points' that most set Christians and Muslims apart ${ }^{48}$. But it also highlighted the main common denominator between both: the 'common filiation' and 'devotion' to the maternal feminine deity, the Virgin Mary, mother of Jesus, Our Lady of Fátima. Only this shared 'love' justified, according to the Bishop, the participation of thousands of people in Niassa, "a large part of which of Muslim religion", in the ceremony of inauguration of the "humble monument to Our Lady of Fátima" in the porch of the seat of the Mecanhelas Mission, and that they had led "in procession", "among hymns and prayers" (Islamic), "an image of the very same Our Lady to the future site of the church".

Similarly, in a letter sent to the Muslims of the province by the Governor General, Baltazar Rebelo de Sousa on 17 December 1968, the latter emphasised connections to "Mohammedans", both at the personal level, and those of the Catholic Church. After highlighting "common [...] truths of faith", he enunciated the "strongest and most actual" value that compelled "Christians and Muslims towards dialogue": the reciprocal veneration of the female deity, "Mary", "Patron Saint of the Portuguese Nation", defined by the "Koran and the H'adîths" as "a Saintly and Pure Virgin, the 'best Woman of the World' ", and of "Fátima, 'the beloved daughter of the Prophet' ", the name of the place chosen by the Virgin "to appear and speak" to Portuguese Christians ${ }^{49}$.

$$
* * *
$$

In the absence of a joint representation of Mozambican colonial society, and as a reaction to the identity vulnerability it originated, the Indian presence was repeatedly characterised in terms of Otherness. The denial of its influence on the global development of colonial society (and its role in the dynamics of exchanges between different racial and socio-cultural strata), or its simultaneous paranoidization as imminent (economic and political) threat to the colonial power were two recurrent reactions. In the gaps between these two colonial subcultures, a third representational framework of colonial society progressively developed, which recognised both reciprocities and functional interdependencies, and even cultural, affective and identity affinities.

47 F.A. Monteiro, 1993b: 86.

48 'The Muslim notion, according to which Jesus Christ is not God, but merely a great prophet', in 'Carta fraterna do Bispo de Vila Cabral aos Muçulmanos da sua Diocese' ['Brotherly Letter of the Bishop of Vila Cabral to the Muslims of His Diocese'], of 6 September 1966, published in MonTEIRo, op. cit: 353.

49 This and other similar letters were broadcast by Mozambican Radio in all the provincial territory shortly before the month of Ramadan of the years 1968, 1969, 1970, and 1972. 
The crisis of 1961, and the narcissic wound it inflicted upon Imperial power did not merely result in the expulsion of thousands of Indians; it also forced colonial powers to officially recognise their (economic) dependence on Indian elites, despite the opposition of certain sectors of the central government and colonial society itself. Similarly, the heightening of the struggle led by the Armed Forces against Mozambican liberation movements resulted not only in a change of strategy in the relations between the Portuguese administration and the Muslim population of the province; it also required the production and dissemination of a new model of colonial relations with regards to difference: the model of an Imperial family in which each one of the 'different' elements partially partook of the nature of the 'other', as 'brothers' identified with the same maternal matrix. This seems to be a possible interpretation of the words of Rebelo de Sousa, according to whom the "tolerance and human affection" characteristic of "the unequalled association" of "continental and Overseas Portugal" resulted from the "love" shared by all those who converged on Portuguese soil from many different lands, for a single, deified mother, a love that compelled them to live "in full togetherness" as brothers that "many times, do not clearly know anymore [...] whence $[\ldots$ their $]$ habits come" $"$.

However, this imaginary of a 'brotherly union' between Portuguese and Indians for the benefit of the same Portuguese mother country was constantly evoked, before and after 1961, by the main leaders of the communities of Indian origin in the colony. Moreover, the frequent use (by Hindus, Sunnis, and Ismailis alike, in the colonial and postcolonial contexts) of the vocabulary and discursive styles typical of the dominant religious ecology, and their insistent recourse to religious translation (of Hindu or Muslims beliefs, ceremonies, divine figures, etc., into their Catholic equivalents), seem to actually suggest a double authorship for the Christian and Muslim (and even Hindu) veneration of Fátima. The influence of family-based metaphors originating in continental Portugal upon the discursive elites of colonial society cannot be denied. However, we can indeed ask ourselves, possibly with a certain irony, which of the discourses is the "blurred" copy of the other; and, more importantly, claim the analytic primacy of the discoursive interplay between Indian leaders and colonial agents in the understanding of the specificities of the family-based model of colonial relations which anticipated the decline of Portuguese colonialism in Mozambique.

October 2006

Susana PEREIRA BASTOS

Universidade Nova de Lisboa, Faculdade de Ciências Sociais e Humanas Centro de Estudos de Migrações e Minorias Étnicas

50 'Mensagem do Governador Geral de Moçambique, B. Rebelo de Sousa, aos Muçulmanos da Província' ['Message from the Governor General of Mozambique, B. Rebelo de Sousa, to the Muslims of the Province'] of 24th November 1969, quoted in MonteIRo, op. cit: 368. 


\section{Bibliography}

AlPers, E.A. 1999, "Islam in the service of Colonialism? Portuguese Strategy during the Armed Liberation Struggle in Mozambique", Lusotopie (Paris, Karthala), VI: 165-184.

Bastos, S. 2005, "Indian Transnationalisms in colonial and postcolonial Mozambique", Vienna Fournal of African Studies, 8 (V): 277-306.

Bastos, S. \& Bastos, J. 2005, “ 'Our colonisers were better than yours': Identity Debates in Greater London", Journal of Ethnic and Migration Studies (London, Routledge), 31 (1): 79-98.

— eds 2006, Filhos diferentes de deuses diferentes. Manejos da religião em processos de inserção social diferenciada: uma abordagem estrutural dinâmica, Lisbon, Alto Comissariado para a Imigração e Minorias Étnicas (ACIME).

Внавна, H. 1994, Location of Culture, London-New York, Routledge.

CAHEN, M. 2000, "L'État Nouveau et la diversification religieuse au Mozambique, 1930-1974", Cahiers d'Études africaines, 158, (XL-2): 309-49.

Dias, A.J. 1956, Minorias étnicas nas provincias ultramarinas, Report of the Center for Political and Social Studies, Lisbon: 11.

Garcia, F. 2001, Análise Global de uma Guerra (Moģambique 1964-1974), Ph.D. thesis, Porto, Universidade Portucalense.

Gosden, C. \& Knowles, C. 2001, Collecting Colonialism: Material Culture and Colonial Change, Oxford, Berg.

Hannerz, U. 1996, Transnational Connections: Culture, People, Places, London-New York, Routledge.

Honwana, A. 1996, Spiritual agency and self renewal in Southern Mozambique, Ph.D. thesis, London, School of Oriental and African Studies, University of London.

MonteIro, F.A. 1993a, O Islão, o Poder e a Guerra (Moçambique 1964-1974), Porto, Universidade Portucalense: $303-311$.

- 1993b, "Sobre a actuação da corrente «wahhabita » no islão moçambicano: algumas notas relativas ao período 1964-1974", Africana, 12.

Moreira, A. 1963, Contribuição de Portugal para a Valorização do Homem no Ultramar, Lisbon, Junta de Investigações do Ultramar: 13 ("Ensaios: Estudos de Ciências Políticas e Sociais", 34).

Rosales, M. 2006, As coisas da casa. Objectos domésticos, memórias e narrativas identitárias de famílias com trajectos transcontinentais, Ph.D. thesis, Lisbon, Universidade Nova de Lisboa, faculdade de Giências Sociais e Humanas.

Salazar A. de Oliveira, 1937, Discursos e notas politicas II (1935-1937), Coimbra, Coimbra Editora. s/d, Discursos e notas politicas III (1938-1943), Coimbra, Coimbra Editora.

— 1951, Discursos e notas politicas IV (1943-1950), Coimbra, Coimbra Editora.

Van der Veer, P. 2001, Imperial Encounters: Religion and Modernity in India and Britain, Princeton, Princeton University Press.

Zamparoni, V. 2000, "Monhés, Baneanes, Chinas e Afro-maometanos. Colonialismo e Racismo em Lourenço Marques, Moçambique (1890-1940)", Lusotopie (Paris, Karthala), VII: 191-222. 